\title{
RESEARCH PAPER \\ DISTRIBUTION OF TOTAL LEAD, COPPER, ZINC AND CADMIUM IN SOILS ALONG THE HIGHWAY FROM TAFO TO ABOASO IN KUMASI IN THE ASHANTI REGION OF GHANA
}

\author{
J. K. Adengala ${ }^{1}$, R. B. Voegborlo ${ }^{2}$, D. Azanu ${ }^{2}$ and J. I. Adam ${ }^{3}$ \\ ${ }^{1}$ Department of Environmental Science, College of Science, KNUST, Kumasi, Ghana \\ ${ }^{2}$ Department of Chemistry, College of Science, KNUST, Kumasi, Ghana \\ ${ }^{3}$ Department of Theoretical and Applied Biology, College of Science, KNUST, Kumasi, Ghana \\ Corresponding author: raybrightv@yahoo.com,rbvoegborlo.sci@knust.edu.gh
}

\begin{abstract}
Levels of some heavy metals in soils along the highway from Tafo to Aboaso in Kumasi in the Ashanti region of Ghana were determined by atomic absorption spectrometry. Soil samples were collected at distances of $5 \mathrm{~m}, 20 \mathrm{~m}$ and $50 \mathrm{~m}$ from the roadside and at depths of 0-5 cm, 5-10 cm and 10-15 cm. Lead concentrations varied from 152.5 to $878.0 \mathrm{mg} \mathrm{kg}^{-1}$,zinc from 65.8 to $712 \mathrm{mg}$ $\mathrm{kg}^{-1}$, copper from 18.8 to $114.8 \mathrm{mg} \mathrm{kg}^{-1}$ and cadmium from 0.80 to $4.5 \mathrm{mg} \mathrm{kg}^{-1}$. The concentrations of Lead, Zinc, Copper and Cadmium all decreased with increasing distance from the road and with decreasing vehicular traffic density indicating their relation to traffic. The concentrations of the metals also decreased with depth in the soil profile indicating that the source of the metals was aerial deposition from motor vehicles. The heavy metal content of the soils for every distance from the roadside was found in the order Lead>Zinc>Copper>Cadmium.
\end{abstract}

Keywords: Roadside soil, vehicular traffic, lead, copper, zinc, cadmium

\section{INTRODUCTION}

Heavy metals are naturally present in soils, water and air. However, roadside soils have been reported to contain high concentrations of metallic contaminants as studies have shown that soils receive extremely large inputs of toxic metals from different anthropogenic sources and especially from automobile emissions (Bakirdere and Yama, 2008; Abechi et al., 2010; Naser et al., 2012). Metals such as Copper $(\mathrm{Cu})$, Iron $(\mathrm{Fe})$, Zinc $(\mathrm{Zn})$, and $\mathrm{Cad}-$ mium $(\mathrm{Cd})$ are essential components of many alloys, wires, tires, and many industrial processes, and could be released into roadside soils and plants as a result of mechanical abrasion and normal tear and wear. For example, lead in street dust and roadside soil has been extensively studied, and found to be present at elevated levels (Bai et al., 2008; Adedeji et al., 2013).

The concentrations of lead in soil and in plants 


\section{Voegborlo et al.}

along major urban highways have been shown to decrease rapidly with distance from the roadside and with decreasing traffic density (Motto et al., 1970; Page et al., 1971; Ward et al., 1977; Voegborlo and Chirgawi, 2007: Adedeji et al., 2013). The source of lead is without doubt from petrol to which has been added lead and this has been well reported. The sources of the other metals which have been documented as roadside contaminants are less well defined than that of lead. Apart from lead, very little concern has been given to the likelihood of pollution by the other heavy metals which can originate from automobiles, tyre wear and motor oils. Lagerweff and Specht (1970) have reported the $\mathrm{Cd}$ content of three lubricating oils to range from 0.20 to $0.26 \mathrm{mg} \mathrm{L}^{-1}$ and that of three diesel oils from 0.07 to $0.10 \mathrm{mg} \mathrm{L}^{-1}$. The $\mathrm{Cd}$ content of four tyres of different brands was also found to range from 20 to $90 \mathrm{mg} \mathrm{kg}^{-1}$. The presence of cadmium, nickel and zinc in addition to lead in soils and grasses at roadside has been reported to be presumably derived from motor vehicle exhausts, tyre wear and motor oils (Lagerweff and Specht 1970; Motto et al., 1970; Ward et al., 1977; Bakirdere and Yaman, 2008; Xia et al., 2011).

The possible hazards arising from pollution of the environment by heavy metals have surfaced more recently, and the toxicity of some of these metals towards humans especially children when exposed to them from the atmosphere, water or food has been well documented (World Health Organization, 1976; Page and Bingham, 1973; Mahaffey, 1977; Abduljaleel et al., 2012). Although there have been a considerable number of studies on concentrations of heavy metals in soils and plants, the vast majority have been carried out in developed countries with long histories of industrialization and extensive use of leaded gasoline (Hjortenkrans et al., 2006; Bai et al., 2008; Adedeji et al., 2013). With the rapid increase in the number of motor vehicles on Ghana's roads recently, considerable amounts of some heavy metals are likely to be emitted regularly as long as the nearby sources remain active. This study focuses on the distribution of $\mathrm{Pb}, \mathrm{Cu}, \mathrm{Zn}$ and $\mathrm{Cd}$ in soils collected from different distances and depth along the Tafo-Aboaso road in $\mathrm{Ku}$ masi in the Ashanti region of Ghana and the correlation between total heavy metals and soil depth and distance from the road.

\section{MATERIALS AND METHODS}

\section{Sample collection and preparation}

The road selected for the study runs northeast from central Kumasi through Tafo, Mamponteng, Ntonso to Asante-Mampong. The portion of the road that was sampled is $12 \mathrm{~km}$ from Tafo the first point of sampling to Aboaso the last point of sampling. The said portion of the road has two major intersections; one at Meduma and the second at Mamponteng. This portion of the road was thus divided into three major sections A, B and C (Fig. 1) according to vehicular traffic density for the purpose of this study.

The vehicular traffic density along section A was about fourteen thousand $(14,000)$ vehicles per day while that along section $\mathrm{B}$ was ten thousand $(10,000)$. The vehicular traffic density was four thousand $(4,000)$ vehicles per day along section C (November 2010).

Within each section, four sampling points were identified and samples from two adjacent points were mixed to form a composite sample. Each section therefore had two sampling points $\left(\mathrm{P}_{1}\right.$ and $\left.\mathrm{P}_{2}\right)$ along the road, three distances $\left(\mathrm{L}_{5}, \mathrm{~L}_{20}\right.$ and $\left.\mathrm{L}_{50}\right)$ and three depths $\left(\mathrm{D}_{5}, \mathrm{D}_{10}\right.$ and $\left.\mathrm{D}_{15}\right)$ to give 18 samples per section of the road and a total of 54 samples. Samples were taken at distances of $5 \mathrm{~m}, 20 \mathrm{~m}$ and $50 \mathrm{~m}$ from the edge of the road and at depths of $0-5 \mathrm{~cm}, 5-10 \mathrm{~cm}$ and 10 $-15 \mathrm{~cm}$. This was to determine the distribution of heavy metals in the soil profile up to $15 \mathrm{~cm}$ depth. Samples were taken at the said depths and distances with a small plastic shovel into clean plastic containers, labeled and transported to the laboratory where samples were air dried and mixed thoroughly and sieved with $2 \mathrm{~mm}$ square holed nylon sieves ready for analysis. One gram of sample was weighed into a $50 \mathrm{~mL}$ 


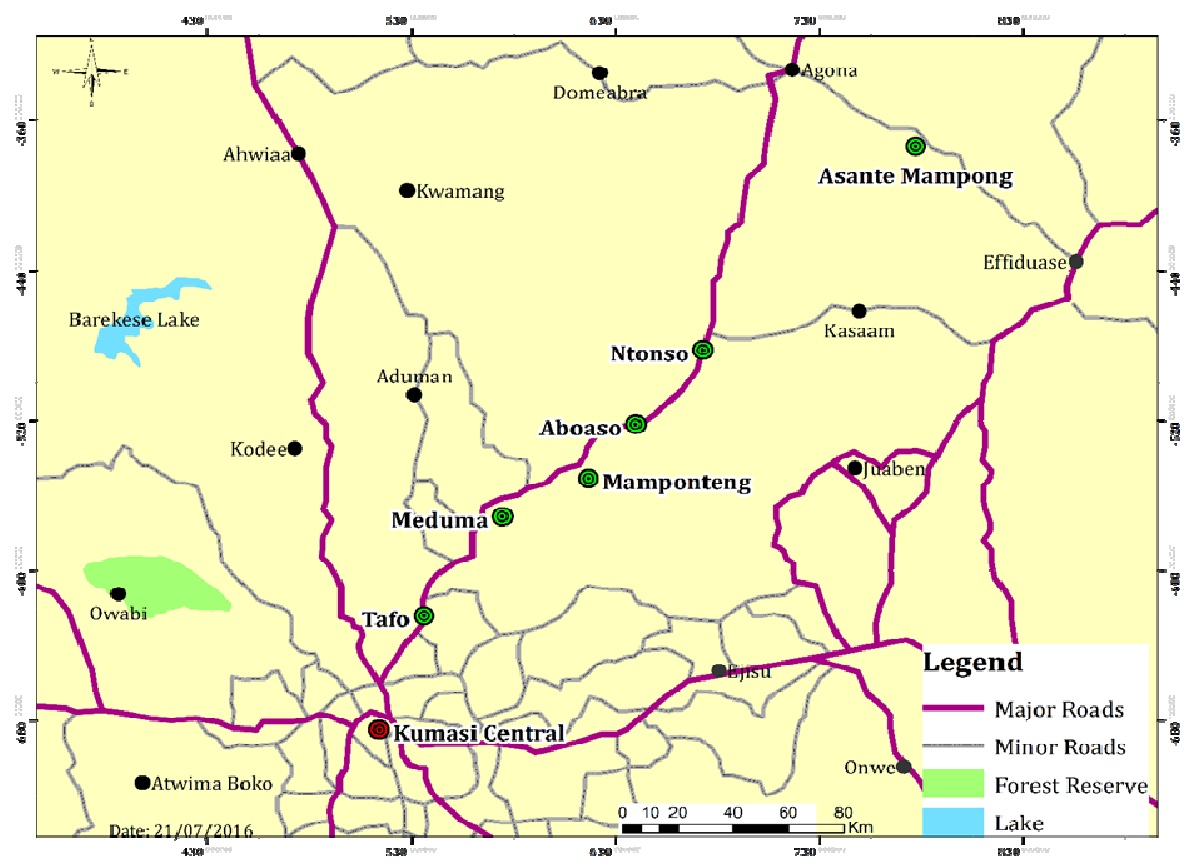

Fig. 1: Map of study sites in Ashanti region of Ghana

graduated digestion tube and $15 \mathrm{~mL}$ aqua regia was added. After leaving it overnight, it was heated at $150^{\circ} \mathrm{C}$ for one hour. The sample was diluted to $50 \mathrm{~mL}$ with deionised water and filtered using Whatman No. 41 filter paper and the filtrate stored for analysis. All extractions were carried out in triplicates and blanks were prepared alongside the samples by the same process of extraction.

All the extracts were analysed for lead $(\mathrm{Pb})$, copper $(\mathrm{Cu})$, zinc $(\mathrm{Zn})$ and cadmium $(\mathrm{Cd})$ by flame atomic absorption spectrometry, (AAS) (Spectra AA 220 Varian Spectrophotometer) which was calibrated using standard solutions of the different metals under investigation. The accuracy of the analytical method used was evaluated by performing a recovery analysis. Recovery of the metals was determined by adding a known amount of an analyte to some samples, which were then taken through the diges- tion procedure. The statistical tools used in this study were linear regression and correlation analysis using Microsoft Excel and one-way analysis of variance (ANOVA) using Statistical Package for Social Sciences (SPSS Version 13.0). These were used to assess the correlation between metal concentration in soil and traffic density, distance from road and depth.

\section{RESULTS AND DISCUSSION}

The accuracy of the analytical technique used in this study was determined by carrying out recoveries. Recoveries for the metals ranged from $90.0 \%$ to $111.4 \%$.

\section{Distribution of total lead with distance from} road and depth in Section A

The levels of total $\mathrm{Pb}$ in surface soils at sampling points at $5 \mathrm{~m}, 20 \mathrm{~m}$ and $50 \mathrm{~m}$ from the road were $710.0,575.0$ and $878.0 \mathrm{mgkg}^{-1}$ respectively. The trend was: levels at $5 \mathrm{~m}>$ levels at 
$50 \mathrm{~m}>$ levels at $20 \mathrm{~m}$. The $\mathrm{Pb}$ levels at sampling point 2 at $5 \mathrm{~m}, 20 \mathrm{~m}$ and $50 \mathrm{~m}$ from the road were $685.0,575.0$ and $265.0 \mathrm{mgkg}^{-1}$ respectively with a trend of levels at $5 \mathrm{~m}>$ levels at $20 \mathrm{~m}>$ levels at $50 \mathrm{~m}$. The mean values however give the trend: levels at $5 \mathrm{~m}>$ levels at $20 \mathrm{~m}>$ levels at $50 \mathrm{~m}$. The difference between the levels at $5 \mathrm{~m}$, $20 \mathrm{~m}$ and $50 \mathrm{~m}$ were found to be insignificant $(\mathrm{P}=0.851)$. The results from this study indicate that levels of $\mathrm{Pb}$ in soils are dependent on distance from the road and reduce with increasing distance from the road and therefore its relation to traffic (Fig. 2).

Similarly, for depth, the variation in the levels of $\mathrm{Pb}$ at $5 \mathrm{~m}$ distance and from $0-5 \mathrm{~cm}, 5-10 \mathrm{~cm}$ and $10-15 \mathrm{~cm}$ depths were $697.5,677.5$ and $446.5 \mathrm{mgkg}-1$ respectively. At $20 \mathrm{~m}$, the levels at $0-5 \mathrm{~cm}, 5-10 \mathrm{~cm}$ and $10-15 \mathrm{~cm}$ depths were $575.0,555.0$ and $302.5 \mathrm{mgkg}^{-1}$ respectively. The levels at $50 \mathrm{~m}$ from the road at $0-5 \mathrm{~cm}, 5-10 \mathrm{~cm}$ and $10-15 \mathrm{~cm}$ depths were 569.0, 483.5 and $390.0 \mathrm{mgkg}^{-1}$ respectively. The general trend observed for the distribution of $\mathrm{Pb}$ in the soil profile was $0-5 \mathrm{~cm}>5-10 \mathrm{~cm}>10-15 \mathrm{~cm}$ (Fig. $2)$. The reduction in concentration with increasing depth indicates surface pollution from a source. Similar trends were observed by Voegborlo et al., (2007).

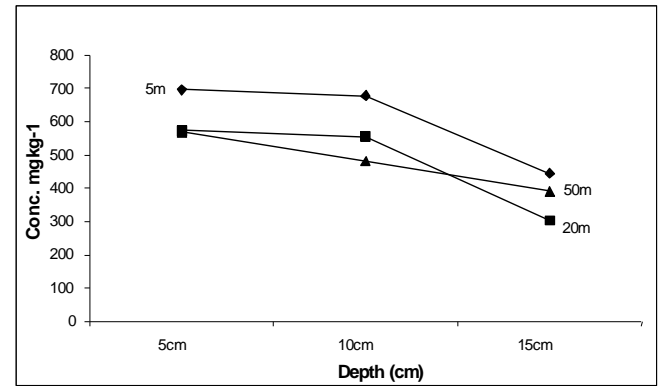

Fig. 2: Pb levels at various distances and depths in section $\mathrm{A}$
Distribution of total lead with distance from road and depth in Section $B$

The results obtained in section B follow a similar trend as in section A except that the concentrations are lower at this section and could be attributed to vehicular traffic. The trend of $\mathrm{Pb}$ distribution in the soils at sampling point 1 was: levels at $5 \mathrm{~m}>$ levels at $20 \mathrm{~m}>$ levels at $50 \mathrm{~m}$. Similar to point 1 , the trend at sampling point 2 was: levels at $5 \mathrm{~m}>$ levels at $20 \mathrm{~m}>$ levels at $50 \mathrm{~m}$. Significant difference existed between the levels at $5 \mathrm{~m}, 20 \mathrm{~m}$ and $50 \mathrm{~m}(\mathrm{P}=0.008)$. The results from this section also show a reduction in $\mathrm{Pb}$ levels with increasing distance from the road and therefore indicating a relation to traffic. The levels of $\mathrm{Pb}$ at $5 \mathrm{~m}$ distance and from 0 $5 \mathrm{~cm}, 5-10 \mathrm{~cm}$ and $10-15 \mathrm{~cm}$ depths were 355.0 , 325.0 and $282.5 \mathrm{mgkg}^{-1}$ respectively. At $20 \mathrm{~m}$, the levels at $0-5 \mathrm{~cm}, 5-10 \mathrm{~cm}$ and $10-15 \mathrm{~cm}$ depths were $341.0,230.0$ and $197.5 \mathrm{mgkg}^{-1}$ respectively. The levels at $50 \mathrm{~m}$ from the road at 0 $-5 \mathrm{~cm}, 5-10 \mathrm{~cm}$ and $10-15 \mathrm{~cm}$ depths were 252.5 , 235.0 and $207.5 \mathrm{mgkg}^{-1}$ respectively. Similar to the trends observed in section $\mathrm{A}$, the general trend observed for the distribution of $\mathrm{Pb}$ in the soil profile in section $\mathrm{B}$ was $0-5 \mathrm{~cm}>5-10 \mathrm{~cm}>$ $10-15 \mathrm{~cm}$ (Fig. 3) indicating surface type of deposition of $\mathrm{Pb}$.

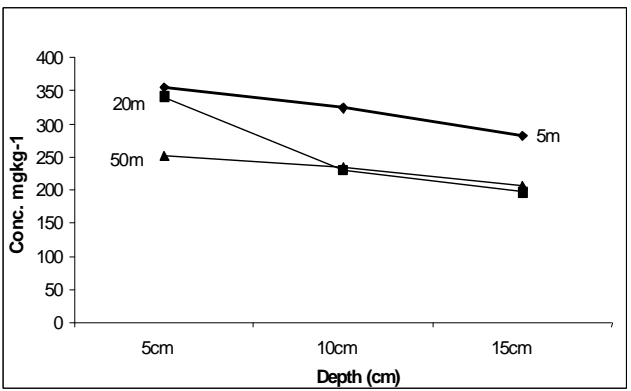

Fig. $3 \mathrm{~Pb}$ levels at various distances and depths in section B 
Distribution of total lead with distance from road and depth in Section $C$

Similar to the distribution pattern in sections A and $\mathrm{B}$, section $\mathrm{C}$ also indicated the trend of $\mathrm{Pb}$ distribution as: at $5 \mathrm{~m}>20 \mathrm{~m}>50 \mathrm{~m}$ for sampling points 1 and 2 . Significant difference existed between the concentrations at $5 \mathrm{~m}, 20 \mathrm{~m}$ and $50 \mathrm{~m}(\mathrm{P}=0.023)$. The results from this section agree with those from sections $\mathrm{A}$ and $\mathrm{B}$ and indicate that concentrations of $\mathrm{Pb}$ in soils is dependent on the distance from the road and decrease with increasing distance from the road. This confirms a relation to the effect of traffic. This section had the lowest concentrations compared to section $\mathrm{A}$ and $\mathrm{B}$ and this is attributed to the lower traffic density in this section. The levels of $\mathrm{Pb}$ at $5 \mathrm{~m}$ distance and from $0-5 \mathrm{~cm}, 5-10 \mathrm{~cm}$ and $10-15 \mathrm{~cm}$ depths were $287.5,280.0$ and $247.5 \mathrm{mgkg}^{-1}$ respectively. At $20 \mathrm{~m}$, the levels at $0-5 \mathrm{~cm}, 5-10 \mathrm{~cm}$ and $10-15 \mathrm{~cm}$ depths were $265.0,242.5$ and $197.5 \mathrm{mgkg}^{-1}$ respectively. The levels at $50 \mathrm{~m}$ from the road at 0 $-5 \mathrm{~cm}, 5-10 \mathrm{~cm}$ and $10-15 \mathrm{~cm}$ depths were 197.5 , 177.5 and $152.5 \mathrm{mgkg}^{-1}$ respectively. The general trend observed for the distribution of $\mathrm{Pb}$ in the soil profile in section $\mathrm{C}$ was $0-5 \mathrm{~cm}>5$ $10 \mathrm{~cm}>10-15 \mathrm{~cm}$ (Fig. 4) indicating surface deposition of $\mathrm{Pb}$. This agrees with the results from sections A and B. Generally the levels of $\mathrm{Pb}$ in surface soils $(0-5 \mathrm{~cm}$ depth) were higher than those from $5-10 \mathrm{~cm}$ which in turn were

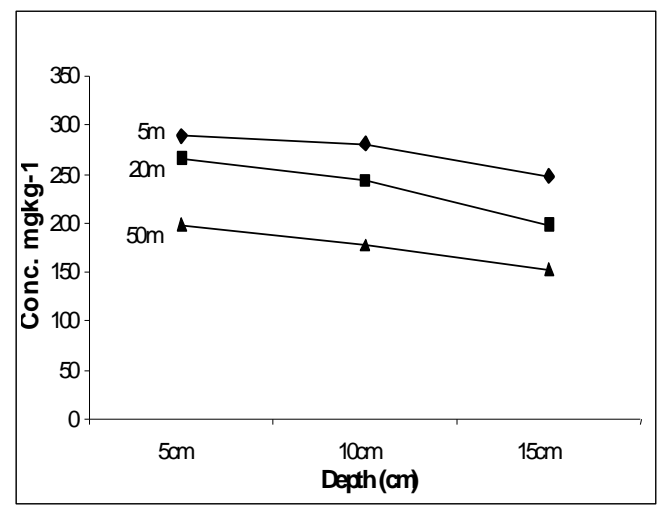

Fig. 4: Pb levels at various distances and depths in section $\mathrm{C}$ higher than those from $10-15 \mathrm{~cm}$ depth i.e. 0 $5 \mathrm{~cm}>5-10 \mathrm{~cm}>10-15 \mathrm{~cm}$. This is because most pollutants are added to the surface soil, and only when the amounts deposited are high is there any significant transfer of the pollutant down the profile by leaching (Chow, 1970, Voegborlo et al., 2007). Again, the levels of $\mathrm{Pb}$ at $5 \mathrm{~m}$ from the road were generally higher than those at $20 \mathrm{~m}$ which were in turn higher than those at $50 \mathrm{~m}$ i.e. $5 \mathrm{~m}>20 \mathrm{~m}>50 \mathrm{~m}$ in all sections. The trends above are in agreement with the studies by Motto et al., (1970); Page et al., (1971); Ward et al., (1977), Rodrigues-Flores, (1982), Adedeji et al., 2013 and Swietlik et al., 2013 who found that the concentrations of lead in soil along major urban highways decrease rapidly with distance from the roadside and with decreasing traffic density.

Distribution of total lead with traffic density

Generally, soils in section A of the road contained more lead $(\mathrm{Pb})$ than those in section $\mathrm{B}$, which in turn had higher $\mathrm{Pb}$ levels than those in section $\mathrm{C}$. The trend was section $\mathrm{A}>\operatorname{section} \mathrm{B}$ $>$ section $C$ for all samples whether at $5 \mathrm{~m}, 20 \mathrm{~m}$ or $50 \mathrm{~m}$ from the road (Fig. 5). The figure shows a more pronounced increase in $\mathrm{Pb}$ concentrations from section $\mathrm{B}$ to section $\mathrm{A}$ compared with section $\mathrm{C}$ to section $\mathrm{B}$. A high correlation was observed between the $\mathrm{Pb}$ content in surface soils and traffic density at $5 \mathrm{~m}$ distance

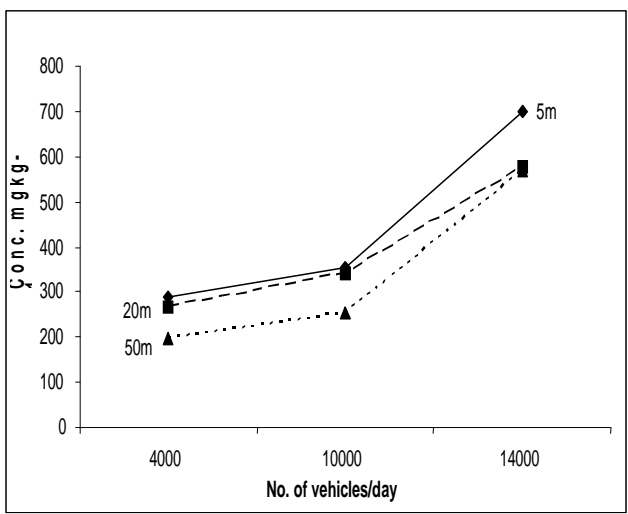

Fig. 5: Pb levels in surface soils in sections $\mathrm{A}, \mathrm{B}, \mathrm{C}$ 
$\left(\mathrm{R}^{2}=0.8696\right.$, Fig. 6). These results agree with the studies of Motto et al., (1970); Page et al., (1971); Ward et al., (1977), Adedeji et al., (2013) and Swietlik et al., (2013) who found that the concentrations of lead in soils along major urban highways decrease rapidly with distance from the roadside and with decreasing traffic density.

Distribution of total zinc with distance from road and depth in Section $A$

The levels of total $\mathrm{Zn}$ in surface soils at sampling point 1 at $5 \mathrm{~m}, 20 \mathrm{~m}$ and $50 \mathrm{~m}$ from the road were $681.00,477.50$ and $712.00 \mathrm{mgkg}^{-1}$ respectively. The trend was: levels at $5 \mathrm{~m}>$ levels at $50 \mathrm{~m}>$ levels at $20 \mathrm{~m}$. For point 2 , the $\mathrm{Zn}$ levels at $5 \mathrm{~m}, 20 \mathrm{~m}$ and $50 \mathrm{~m}$ from the road were $658.00,471.50$ and $241.50 \mathrm{mgkg}^{-1}$ respectively with a trend of $5 \mathrm{~m}>$ levels at $20 \mathrm{~m}>$ levels at $50 \mathrm{~m}$. The mean values give the trend as: levels at $5 \mathrm{~m}>$ levels at $50 \mathrm{~m}>$ levels at $20 \mathrm{~m}$. The differences between the levels at $5 \mathrm{~m}, 20 \mathrm{~m}$ and $50 \mathrm{~m}$ were found to be insignificant $(\mathrm{P}=0.572)$. For depth variation, the levels of $\mathrm{Zn}$ at $5 \mathrm{~m}$ distance and from $0-5 \mathrm{~cm}, 5-10 \mathrm{~cm}$ and $10-15 \mathrm{~cm}$ depths were $669.50,564.50$ and $356.50 \mathrm{mgkg}^{-1}$ respectively. At $20 \mathrm{~m}$, the levels at $0-5 \mathrm{~cm}, 5-$ $10 \mathrm{~cm}$ and $10-15 \mathrm{~cm}$ depths were $474.50,336.50$ and $305.00 \mathrm{mgkg}^{-1}$ respectively and the levels at $50 \mathrm{~m}$ from the road at $0-5 \mathrm{~cm}, 5-10 \mathrm{~cm}$ and $10-$ $15 \mathrm{~cm}$ depths were $476.75,397.75$ and 382.25

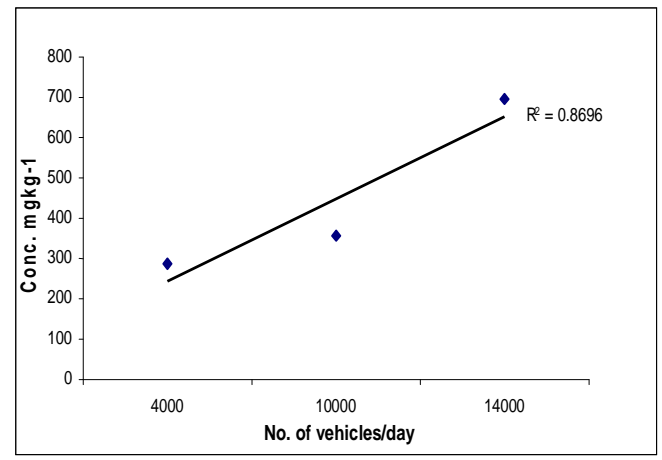

Fig. 6: Correlation of $\mathrm{Pb}$ levels in surface soils at $5 \mathrm{~m}$ with traffic density $\mathrm{mgkg}^{-1}$ respectively. The general trend observed for the distribution of $\mathrm{Zn}$ in the soil profile was $0-5 \mathrm{~cm}>5-10 \mathrm{~cm}>10-15 \mathrm{~cm}$ (Fig. 7). The change in concentration with depth indicates a surface pollution from a source.

\section{Distribution of total zinc with distance from} road and depth in Section $B$

The trend of $\mathrm{Zn}$ distribution in the soils at sampling point 1 was: levels at $5 \mathrm{~m}>$ levels at $20 \mathrm{~m}$ $>$ levels at $50 \mathrm{~m}$. Similar to point1, the trend at sampling point 2 was: levels at $5 \mathrm{~m}>$ levels at $20 \mathrm{~m}>$ levels at $50 \mathrm{~m}$. Significant difference existed between the levels at $5 \mathrm{~m}, 20 \mathrm{~m}$ and $50 \mathrm{~m}$ $(\mathrm{P}=0.000)$. The results from this section show a reduction in $\mathrm{Zn}$ concentration with increasing distance from the road and therefore a relation due to the effect of traffic. The lower $\mathrm{Zn}$ concentration in this section as compared to section A could be attributed to the lower traffic density. Similarly, for variation in depth, the levels of $\mathrm{Zn}$ at $5 \mathrm{~m}$ distance and at $0-5 \mathrm{~cm}, 5-10 \mathrm{~cm}$ and $10-15 \mathrm{~cm}$ depths were $669.50,564.50$ and $356.50 \mathrm{mgkg}^{-1}$ respectively. At $20 \mathrm{~m}$, the $\mathrm{Zn}$ levels at $0-5 \mathrm{~cm}, 5-10 \mathrm{~cm}$ and $10-15 \mathrm{~cm}$ depths were $474.50,336.50$ and $305.00 \mathrm{mgkg}^{-1}$ respectively. The levels at $50 \mathrm{~m}$ from the road at 0 $5 \mathrm{~cm}, 5-10 \mathrm{~cm}$ and $10-15 \mathrm{~cm}$ depths were 476.75 , 397.75 and $382.25 \mathrm{mgkg}^{-1}$ respectively. A plot of $\mathrm{Zn}$ concentration against depth indicates that at all the sampling points, the $\mathrm{Zn}$ levels reduced

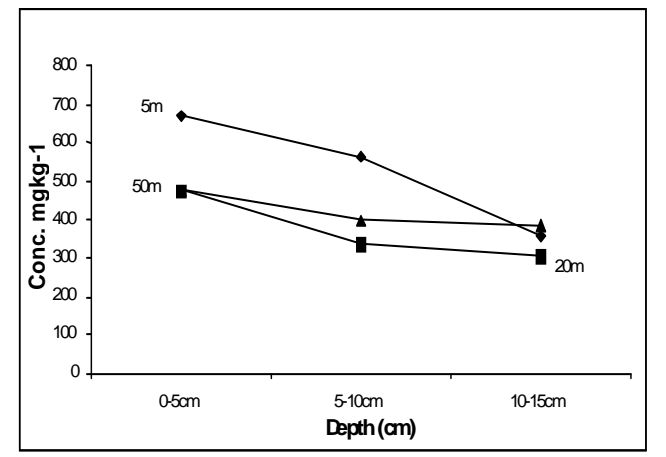

Fig. 7; Zn levels at various distances and depths in section $\mathrm{A}$ 
at lower depths irrespective of the section or the distance from the road (Fig. 8). Similar to the trends observed in section $\mathrm{A}$, the general trend was $0-5 \mathrm{~cm}>5-10 \mathrm{~cm}>10-15 \mathrm{~cm}$ indicating surface type of deposition of $\mathrm{Zn}$.

\section{Distribution of total zinc with distance from} road and depth in Section $C$

There was a reduction in $\mathrm{Zn}$ levels with increasing distance from the road. The trend was concentration at $5 \mathrm{~m}>$ concentration at $20 \mathrm{~m}>$ concentration at $50 \mathrm{~m}$ for sampling points 1 and 2. Significant difference existed between the levels at $5 \mathrm{~m}, 20 \mathrm{~m}$ and $50 \mathrm{~m}(\mathrm{P}=0.015)$. The results from this section like those from section $\mathrm{B}$ indicate that the levels of $\mathrm{Zn}$ in soils is dependent on distance from the road and decreases with increasing distance from the road to confirm a relation to traffic. The levels of $\mathrm{Zn}$ at $5 \mathrm{~m}$ distance and from $0-5 \mathrm{~cm}, 5-10 \mathrm{~cm}$ and $10-15 \mathrm{~cm}$ depths were $249.50,238.50$ and $165.75 \mathrm{mgkg}^{-1}$ respectively. At $20 \mathrm{~m}$, the levels at $0-5 \mathrm{~cm}, 5-$ $10 \mathrm{~cm}$ and $10-15 \mathrm{~cm}$ depths were $140.00,97.25$ and $65.75 \mathrm{mgkg}^{-1}$ respectively. The levels at $50 \mathrm{~m}$ from the road at $0-5 \mathrm{~cm}, 5-10 \mathrm{~cm}$ and 10 $15 \mathrm{~cm}$ depths were $87.50,84.75$ and $75.00 \mathrm{mgkg}^{-}$ ${ }^{1}$ respectively. The general trend observed for the distribution of $\mathrm{Zn}$ in the soil profile in section $\mathrm{C}$ was $0-5 \mathrm{~cm}>5-10 \mathrm{~cm}>10-15 \mathrm{~cm}$ (Fig. 9) indicating surface deposition of $\mathrm{Zn}$ by traffic.

Generally the levels of $\mathrm{Zn}$ in surface soils (0$5 \mathrm{~cm}$ depth) were higher than those from 5$10 \mathrm{~cm}$ which in turn were higher than those from $10-15 \mathrm{~cm}$ depth i.e. $0-5 \mathrm{~cm}>5-10 \mathrm{~cm}>10$ $15 \mathrm{~cm}$. This is because most pollutants fall outs are deposited at the surface of soils, and it is only when the concentrations are high that there will be significant transfer of the pollutant down the profile through leaching (Chow, 1970). The spread of zinc away from the road in section A was less defined. This may be due to the topology of the section A. In sections B and $\mathrm{C}$ however, the levels of $\mathrm{Zn}$ at $5 \mathrm{~m}$ from the road were higher than those at $20 \mathrm{~m}$, which were in turn higher than those at $50 \mathrm{~m}$. Generally, the spread of $\mathrm{Zn}$ away from the road was $5 \mathrm{~m}>20 \mathrm{~m}>50 \mathrm{~m}$. The trends observed in this study are in agreement with other studies (Adedeji et al., 2013 and Swietlik et al., 2013).

Distribution of total zinc with traffic density A plot of total $\mathrm{Zn}$ content in roadside soil against traffic density shows that $\mathrm{Zn}$ increases in soil with increasing traffic density (Fig.10). Generally, soils in section A contained more zinc than those in section $\mathrm{B}$ which in turn contained more than those in section $\mathrm{C}$. The trend

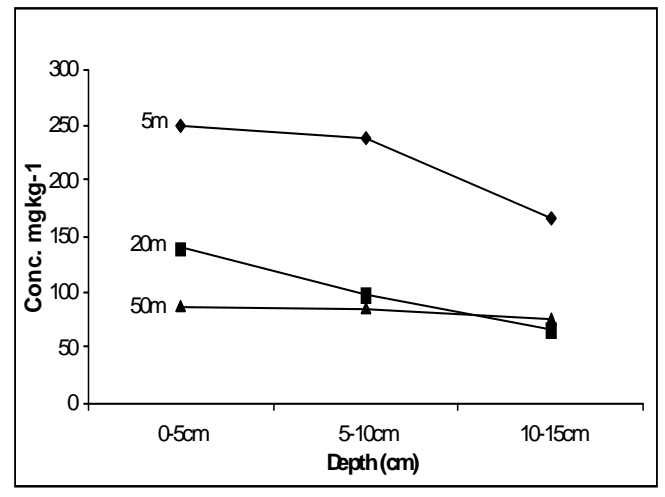

Fig. 8: Zn levels at various distances and depths in section $B$

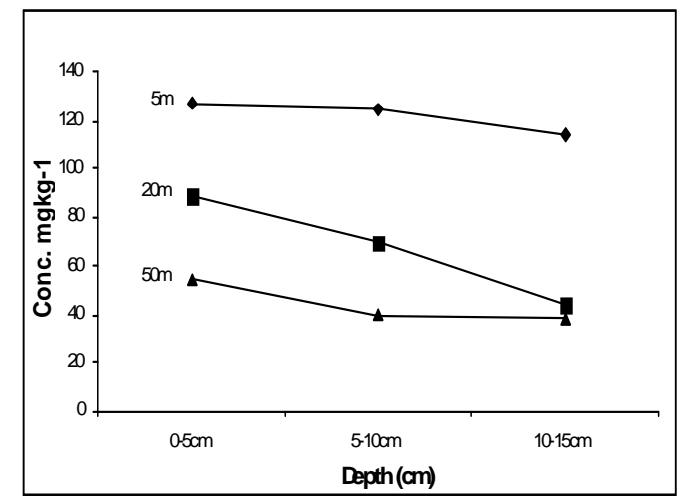

Fig. 9: $\mathrm{Zn}$ levels at various distances and depths in section $\mathrm{C}$ 
in the section was: $\mathrm{A}>$ section $\mathrm{B}>$ section $\mathrm{C}$ for all samples at $5 \mathrm{~m}, 20 \mathrm{~m}$ and $50 \mathrm{~m}$ from the road. The figure shows a more pronounced decrease in metal concentrations from section A to section B compared with section B to section $\mathrm{C}$. In this study, a high correlation between $\mathrm{Zn}$ contents in the soil and traffic density was observed at $5 \mathrm{~m}$ distance from the road $\left(\mathrm{r}^{2}=\right.$ 0.9087, Fig. 11).

Distribution of total copper with distance from road and depth in Section $A$

The levels of total $\mathrm{Cu}$ in surface soils at sampling point 1 at $5 \mathrm{~m}, 20 \mathrm{~m}$ and $50 \mathrm{~m}$ from the road were $113.35,105.44$ and $114.84 \mathrm{mgkg}^{-1}$ respectively. The trend was: levels at $50 \mathrm{~m}>$ levels at $5 \mathrm{~m}>$ levels at $20 \mathrm{~m}$. The $\mathrm{Cu}$ levels at sampling point 2 at $5 \mathrm{~m}, 20 \mathrm{~m}$ and $50 \mathrm{~m}$ from the road were $112.60,103.56$ and $85.11 \mathrm{mgkg}^{-1}$ respectively. The trend was: levels at $5 \mathrm{~m}>$ levels at $20 \mathrm{~m}>$ levels at $50 \mathrm{~m}$. The mean values however give the trend as $5 \mathrm{~m}>$ levels at $20 \mathrm{~m}>$ levels at 50m (Table 3). Significant difference existed between the levels at $5 \mathrm{~m}, 20 \mathrm{~m}$ and $50 \mathrm{~m}$ $(\mathrm{P}=0.003)$. The results from this study indicate that the levels of $\mathrm{Cu}$ in soils are dependent on the distance from the road and reduce with increasing distance from road edges and therefore its relation to traffic. For the depths, the levels of $\mathrm{Cu}$ at $5 \mathrm{~m}$ distance and with $0-5 \mathrm{~cm}, 5-10 \mathrm{~cm}$ and $10-15 \mathrm{~cm}$ depths were $112.97,108.08$ and $87.56 \mathrm{mgkg}^{-1}$ respectively. At $20 \mathrm{~m}$, the levels at $0-5 \mathrm{~cm}, 5-10 \mathrm{~cm}$ and $10-15 \mathrm{~cm}$ depths were $105.82,100.92$ and $82.09 \mathrm{mgkg}^{-1}$ respectively. The levels at $50 \mathrm{~m}$ from the road at $0-5 \mathrm{~cm}, 5-$ $10 \mathrm{~cm}$ and $10-15 \mathrm{~cm}$ depths were $99.97,78.32$ and $57.81 \mathrm{mgkg}^{-1}$ respectively. The general trend observed for the distribution of $\mathrm{Cu}$ in the soils profile was $0-5 \mathrm{~cm}>5-10 \mathrm{~cm}>10-15 \mathrm{~cm}$ (Fig. 12). The change in concentration with depth indicates surface pollution from a source.

\section{Distribution of total copper with distance from road and depth for Section $B$}

The trend of $\mathrm{Cu}$ distribution in the soils at sampling point 1 was: levels at $5 \mathrm{~m}>$ levels at $20 \mathrm{~m}$ $>$ levels at $50 \mathrm{~m}$.Similar to point 1 , the trend at sampling point 2 was: $5 \mathrm{~m}>20 \mathrm{~m}>50 \mathrm{~m}$. A significant difference existed between the levels at $5 \mathrm{~m}, 20 \mathrm{~m}$ and $50 \mathrm{~m}(\mathrm{P}=0.035)$. The results from this section also show a reduction in $\mathrm{Cu}$ levels with increased distance from the road and therefore related to traffic. The levels of $\mathrm{Cu}$ at $5 \mathrm{~m}$ distance and from $0-5 \mathrm{~cm}, 5-10 \mathrm{~cm}$ and $10-15 \mathrm{~cm}$ depths were $83.98,81.72$ and $60.82 \mathrm{mgkg}^{-1}$ respectively. At $20 \mathrm{~m}$, the levels at $0-5 \mathrm{~cm}, 5-10 \mathrm{~cm}$ and $10-15 \mathrm{~cm}$ depths were $74.94,70.61$ and $50.09 \mathrm{mgkg}^{-1}$ respectively. The

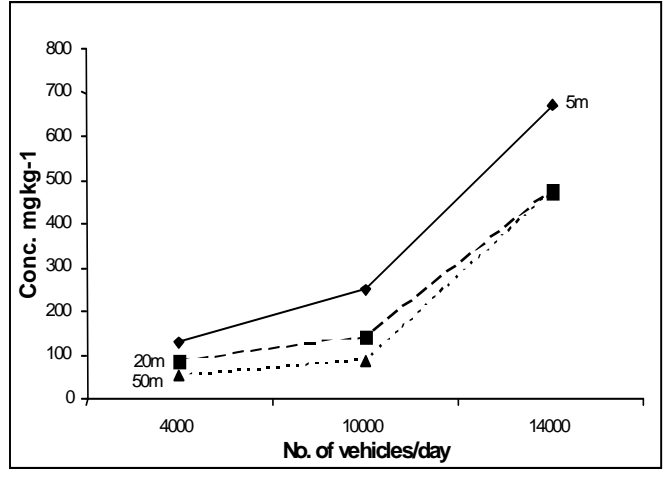

Fig. 10: $\mathrm{Zn}$ levels in surface soils in sections $\mathrm{A}, \mathrm{B}, \mathrm{C}$

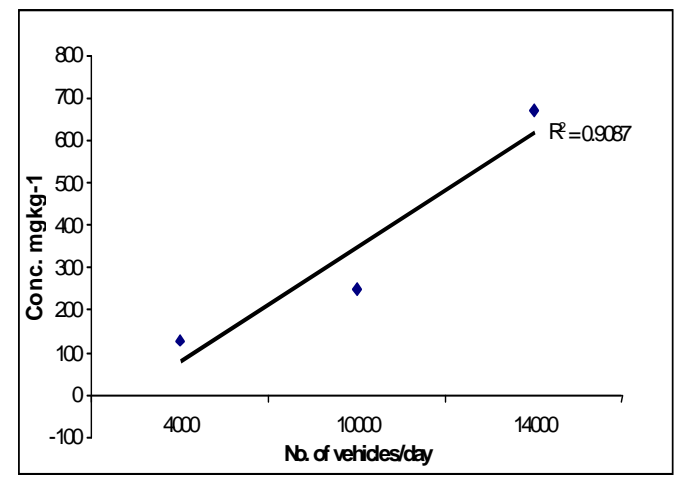

Fig. 11: Correlation of $\mathrm{Zn}$ levels in surface soils with traffic density 


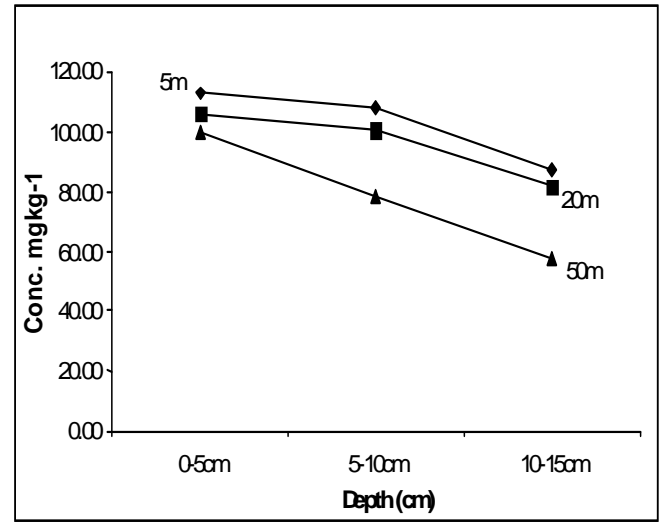

Fig. 12: $\mathrm{Cu}$ levels at various distances and depths in section $A$

levels at $50 \mathrm{~m}$ from the road at $0-5 \mathrm{~cm}, 5-10 \mathrm{~cm}$ and $10-15 \mathrm{~cm}$ depths were $56.11,49.52$ and $39.54 \mathrm{mgkg}^{-1}$ respectively. Similar to the trends observed in section $\mathrm{A}$, the general trend observed for the distribution of $\mathrm{Cu}$ in the soil profile in section $B$ was $0-5 \mathrm{~cm}>5-10 \mathrm{~cm}>10$ $15 \mathrm{~cm}$ (Fig. 13) indicating a surface deposition of $\mathrm{Cu}$.

\section{Distribution of total copper with distance from road and depth for Section $C$}

Similar to the distribution pattern in section B, section $\mathrm{C}$ indicated a trend of $\mathrm{Cu}$ distribution as: levels at $5 \mathrm{~m}>$ levels at $20 \mathrm{~m}>$ levels at $50 \mathrm{~m}$ for sampling points 1 and 2. Significant differences existed between the levels at $5 \mathrm{~m}, 20 \mathrm{~m}$ and $50 \mathrm{~m}(\mathrm{P}=0.023)$. The results observed from this section agree with those from sections $\mathrm{A}$ and $\mathrm{B}$ and indicate that the $\mathrm{Cu}$ concentration in roadside soils is dependent on the distance from the road and decreases with increasing distance from the road. This confirm a relation to traffic. The levels of $\mathrm{Cu}$ at $5 \mathrm{~m}$ distance and from 0 $5 \mathrm{~cm}, 5-10 \mathrm{~cm}$ and $10-15 \mathrm{~cm}$ depths were 39.16 , 35.21 and $32.20 \mathrm{mgkg}^{-1}$ respectively. At $20 \mathrm{~m}$, the levels were $28.43,25.98$ and $22.78 \mathrm{mgkg}^{-1}$

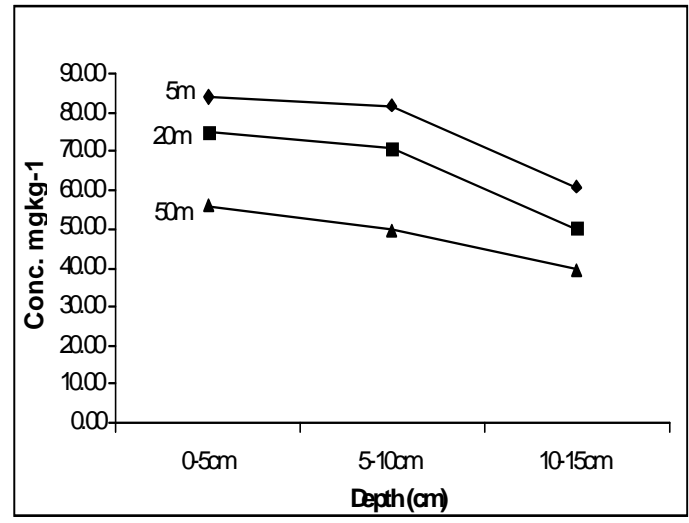

Fig. 13: Cu levels at various distances and depths in section $B$

respectively and at $50 \mathrm{~m}$ the levels were 22.78 , 19.77 and $18.83 \mathrm{mgkg}^{-1}$ respectively. The general trend observed for the distribution of $\mathrm{Cu}$ in the soil profile in section $\mathrm{C}$ was $0-5 \mathrm{~cm}>5$ $10 \mathrm{~cm}>10-15 \mathrm{~cm}$ (Fig. 14) indicating surface deposition of $\mathrm{Cu}$. This confirms with the results from sections A and B. This study shows that at all points, the concentration of $\mathrm{Cu}$ decreased with increasing distance from the road. Generally the trend was concentration at $5 \mathrm{~m}>$ concentration at $20 \mathrm{~m}>$ concentration at $50 \mathrm{~m}$ in all sections of the road. The results agree with that of other authors who found a significant correlation between traffic density and $\mathrm{Cu}$ concentrations (Adedeji et al., 2013; Swietlik et al., 2013). All sample points indicated a reduction in $\mathrm{Cu}$ levels at lower depths. The trend was 0$5 \mathrm{~cm}>5-10 \mathrm{~cm}>10-15 \mathrm{~cm}$ indicating aerial deposition of $\mathrm{Cu}$ in the soils in agreement with the studies of Motto et al., (1970); Ward et al., (1977) and Rodrigues-Flores (1982).

Distribution of total copper with traffic density

Generally, soils in the first section of the road where vehicular traffic was high had higher $\mathrm{Cu}$ 


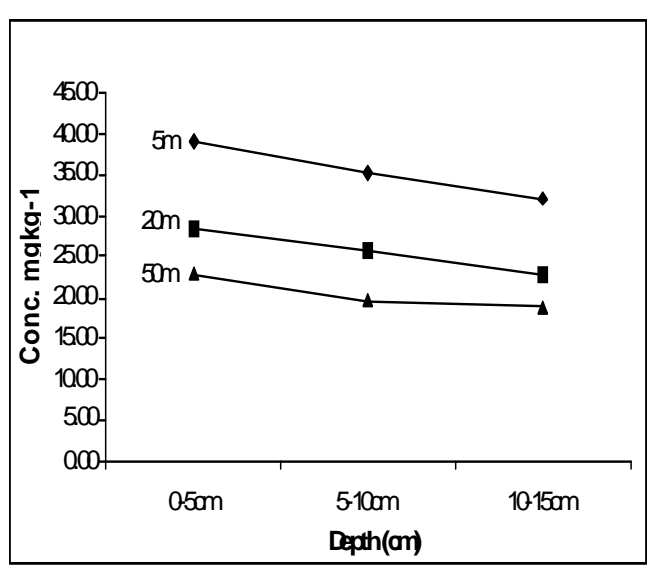

Fig. 14: $\mathrm{Cu}$ levels at various distances and depths in section $\mathrm{C}$

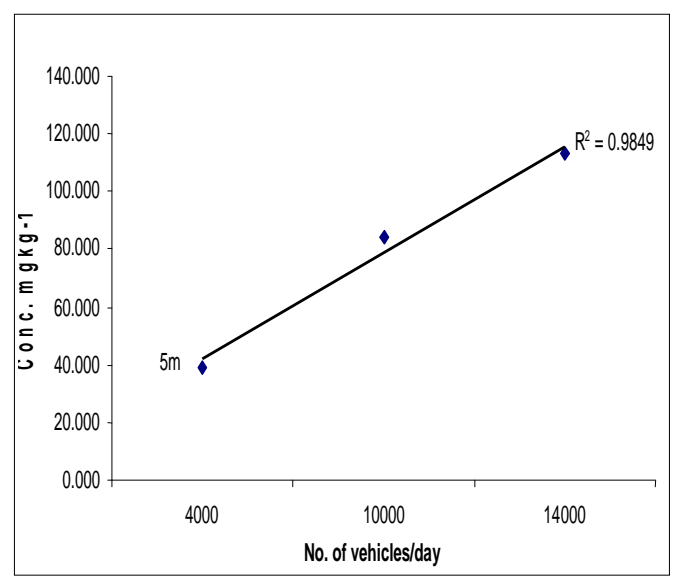

Fig. 16: Correlation of $\mathrm{Cu}$ levels in surface soils with traffic density

concentrations than soils in the second section, which in turn had higher $\mathrm{Cu}$ concentrations than those in the third section where vehicular traffic was least. The trend was: section $\mathrm{A}>$ section $B>$ section $C$ at $5 \mathrm{~m}, 20 \mathrm{~m}$ and $50 \mathrm{~m}$ from the road (Fig.14). A plot of Cu levels in surface soils against traffic density shows a high corre-

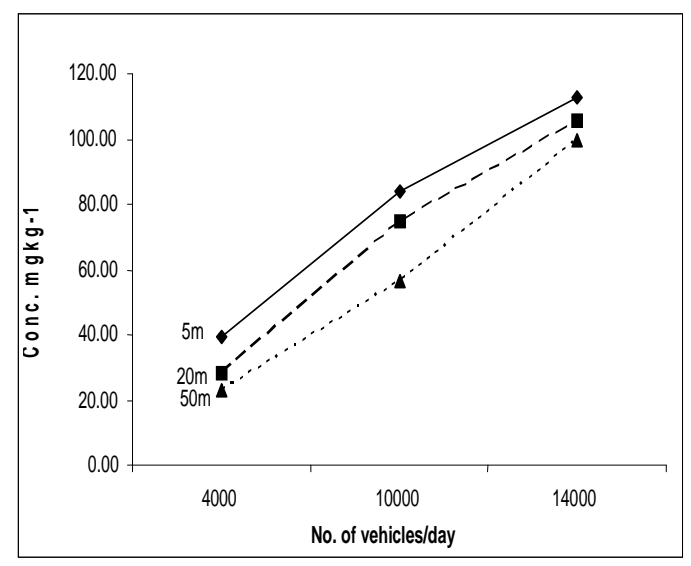

Fig. 15: $\mathrm{Cu}$ levels in surface soils in sections $\mathrm{A}, \mathrm{B}, \mathrm{C}$

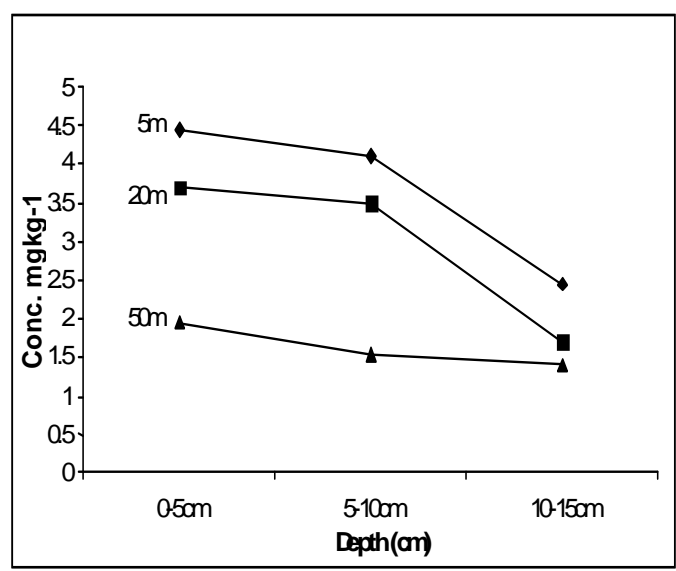

Fig. 17: Cd levels at various distances and depths in section $A$

lation between the $\mathrm{Cu}$ content in soils and traffic density $\left(\mathrm{R}^{2}=9849\right.$, Fig. 16). Other authors (Adedeji et al., 2013 and Swietlik et al., 2013) also found a significant correlation between traffic density and $\mathrm{Cu}$. 
Distribution of total cadmium with distance from road and depth in Section $A$

The levels of total $\mathrm{Cd}$ in surface soils at sampling point 1 at $5 \mathrm{~m}, 20 \mathrm{~m}$ and $50 \mathrm{~m}$ from the road were $4.50,3.90$ and $2.00 \mathrm{mgkg}^{-1}$ respectively. The trend was: levels at $5 \mathrm{~m}>$ levels at $50 \mathrm{~m}>$ levels at $20 \mathrm{~m}$. The $\mathrm{Cd}$ levels at sampling point 2 at $5 \mathrm{~m}, 20 \mathrm{~m}$ and $50 \mathrm{~m}$ from the road were $4.40,3.50$ and $1.90 \mathrm{mgkg}^{-1}$ respectively with a trend of $5 \mathrm{~m}>20 \mathrm{~m}>50 \mathrm{~m}$. Significant differences existed between the levels at $5 \mathrm{~m}, 20 \mathrm{~m}$ and $50 \mathrm{~m}(\mathrm{P}=0.047)$. The results from this study indicate the presence of $\mathrm{Cd}$ in soils is dependent on the distance from the road and this reduces with increasing distance from the road and therefore its relation to traffic. For depth, the levels of $\mathrm{Cd}$ at $5 \mathrm{~m}$ distance at $0-5 \mathrm{~cm}, 5-$ $10 \mathrm{~cm}$ and $10-15 \mathrm{~cm}$ depths were $4.45,4.10$ and $2.45 \mathrm{mgkg}^{-1}$ respectively. At $20 \mathrm{~m}$, the levels at 0 $-5 \mathrm{~cm}, 5-10 \mathrm{~cm}$ and $10-15 \mathrm{~cm}$ depths were 3.70 , 3.50 and $1.70 \mathrm{mgkg}^{-1}$ respectively. The levels at $50 \mathrm{~m}$ from the road at $0-5 \mathrm{~cm}, 5-10 \mathrm{~cm}$ and $10-$ $15 \mathrm{~cm}$ depths were $1.95,1.55$ and $1.40 \mathrm{mgkg}^{-1}$ respectively. The trend observed for the distribution of $\mathrm{Cd}$ in the soil profile in section $\mathrm{A}$ was $0-5 \mathrm{~cm}>5-10 \mathrm{~cm}>10-15 \mathrm{~cm}$ (Fig. 17). The change in concentration with depth indicates surface pollution from a source.

\section{Distribution of total cadmium with distance from road and depth in Section B}

The trend in Cd distribution in the soils at sampling point 1 stood at: levels at $5 \mathrm{~m}>$ levels at $20 \mathrm{~m}>$ levels at $50 \mathrm{~m}$. Similar to point1, the trend at sampling point 2 was: levels at $5 \mathrm{~m}$ $>$ levels at $20 \mathrm{~m}>$ levels at $50 \mathrm{~m}$. Significant difference existed between the levels at $5 \mathrm{~m}$, $20 \mathrm{~m}$ and $50 \mathrm{~m}(\mathrm{P}=0.036)$. The results from this section like those from section $\mathrm{A}$, show a reduction in $\mathrm{Cd}$ levels with increasing distance from the road and therefore related to traffic.

Similarly for depth, the levels of $\mathrm{Cd}$ at $5 \mathrm{~m}$ distance and from $0-5 \mathrm{~cm}, 5-10 \mathrm{~cm}$ and $10-15 \mathrm{~cm}$ depths were $2.95,2.45$ and $1.95 \mathrm{mgkg}^{-1}$ respectively. At $20 \mathrm{~m}$, the levels at $0-5 \mathrm{~cm}, 5-10 \mathrm{~cm}$ and $10-15 \mathrm{~cm}$ depths were $2.35,1.65$ and $1.30 \mathrm{mgkg}^{-}$ ${ }^{1}$ respectively. Similarly, the levels at $50 \mathrm{~m}$ from the road at $0-5 \mathrm{~cm}, 5-10 \mathrm{~cm}$ and $10-15 \mathrm{~cm}$ depths were $1.50,1.35$ and $1.25 \mathrm{mgkg}^{-1}$ respectively. A plot of $\mathrm{Cd}$ concentration against depth indicates that at all sample points the $\mathrm{Cd}$ levels reduced at lower depths irrespective of the distance from the road (Fig. 18). Similarly to the trends observed in section $\mathrm{A}$, the general trend was 0 $5 \mathrm{~cm}>5-10 \mathrm{~cm}>10-15 \mathrm{~cm}$ indicating surface deposition of $\mathrm{Cd}$.

\section{Distribution of total cadmium with distance from road and depth in Section C}

Generally, there was a reduction in $\mathrm{Cd}$ levels with increasing distance from the road. The trend in concentration of the metal at $5 \mathrm{~m}>$ concentration at $20 \mathrm{~m}>$ concentration at $50 \mathrm{~m}$ for sampling points 1 and 2. Significant difference existed between the levels at $5 \mathrm{~m}, 20 \mathrm{~m}$ and $50 \mathrm{~m}$ $(\mathrm{P}=0.006)$. The results from this section show that the levels of $\mathrm{Cd}$ in soils decreased with increasing distance from the road. This indicate that the levels of $\mathrm{Cd}$ in soils dependent on the distance from the road and could be as a result of traffic deposition. The levels of $\mathrm{Cd}$ at $5 \mathrm{~m}$ distance and at $0-5 \mathrm{~cm}, 5-10 \mathrm{~cm}$ and $10-15 \mathrm{~cm}$ depths were $1.85,1.75$ and $1.25 \mathrm{mgkg}^{-1}$ respectively. At $20 \mathrm{~m}$, the corresponding levels were $1.50,1.30$ and $1.05 \mathrm{mgkg}^{-1}$ respectively and at $50 \mathrm{~m}$ the levels stood at 1.20, 1.15 and $0.80 \mathrm{mgkg}^{-1}$ respectively. The general trend observed for the distribution of $\mathrm{Cd}$ in the soil profile in section $\mathrm{C}$ was $0-5 \mathrm{~cm}>5-10 \mathrm{~cm}>10$ $15 \mathrm{~cm}$ (Fig. 19) indicating surface deposition of Cd.

The amount of cadmium in the soils always decreased at lower depths for all sample points. Generally the levels of $\mathrm{Cd}$ in surface soils (0$5 \mathrm{~cm}$ depth) were higher than those from 5$10 \mathrm{~cm}$ which in turn were higher than those from $10-15 \mathrm{~cm}$ depth i.e. $0-5 \mathrm{~cm}>5-10 \mathrm{~cm}>10$ $15 \mathrm{~cm}$. This is because most pollutants are deposited at the surface soil, and only when the amounts deposited are high that there is any significant transfer of the pollutant down the profile through leaching (Chow, 1970). There was a reduction in $\mathrm{Cd}$ levels as one moved away from the road. The trend was concentra- 


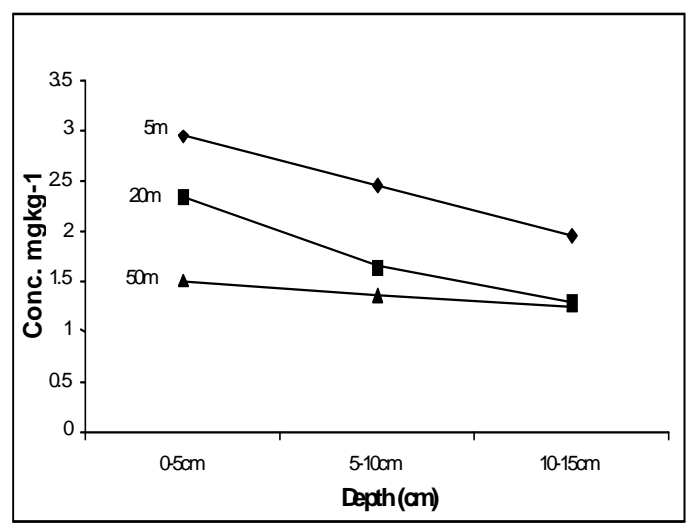

Fig. 18: Cd levels at various distances and depths in section $B$

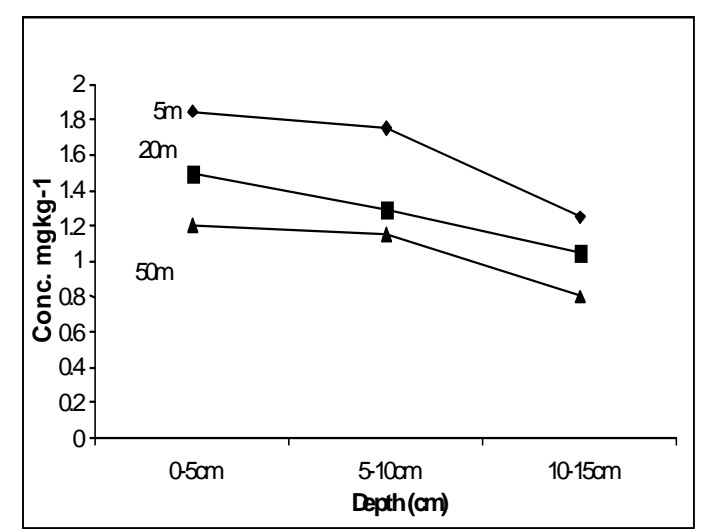

Fig. 19: Cd levels at various distances and depths in section $\mathrm{C}$

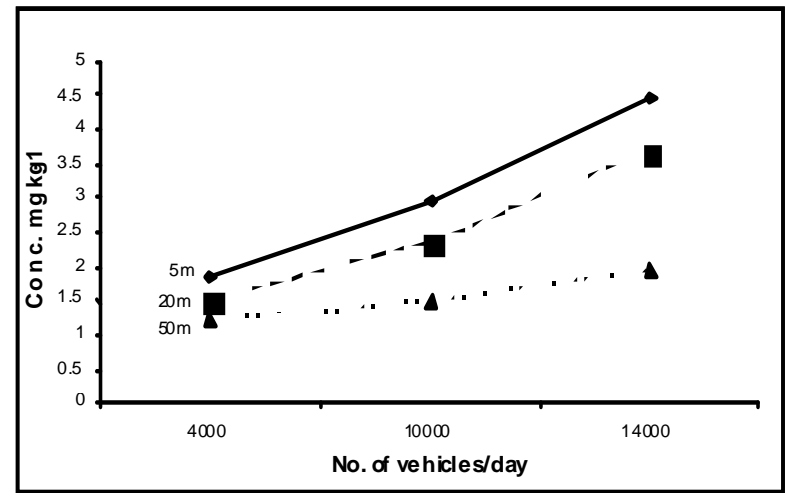

Fig. 20: Cd levels in surface soils in sections A, B, C

tion at $5 \mathrm{~m}>$ concentration at $20 \mathrm{~m}>$ concentration at $50 \mathrm{~m}$ in all sections of the road. Motto et al., (1970) and Ward et al., (1977) found that the concentrations of $\mathrm{Cd}$ in roadside soils were attributable to vehicular traffic and that the amounts decreased with distance from the roadside and as traffic density decreased.

Distribution of total cadmium with traffic density

Generally, the order of total Cd levels in the soils was: section $\mathrm{A}>$ section $\mathrm{B}>\operatorname{section} \mathrm{C}$ at all the distances when one moved away from the edges of the road (Fig. 20). The Cd levels thus reduced with decreasing traffic density. Rodrigues-Flores (1982) also reported same. A strong correlation $\left(\mathrm{R}^{2}=0.9922\right)$ was found existing between the $\mathrm{Cd}$ concentration in surface soils at $5 \mathrm{~m}$ distance and traffic density (Fig. $21)$. These results agree with the work of others (Adedeji et al., 2013 and Swietlik et al., 2013) who found a significant correlation between 


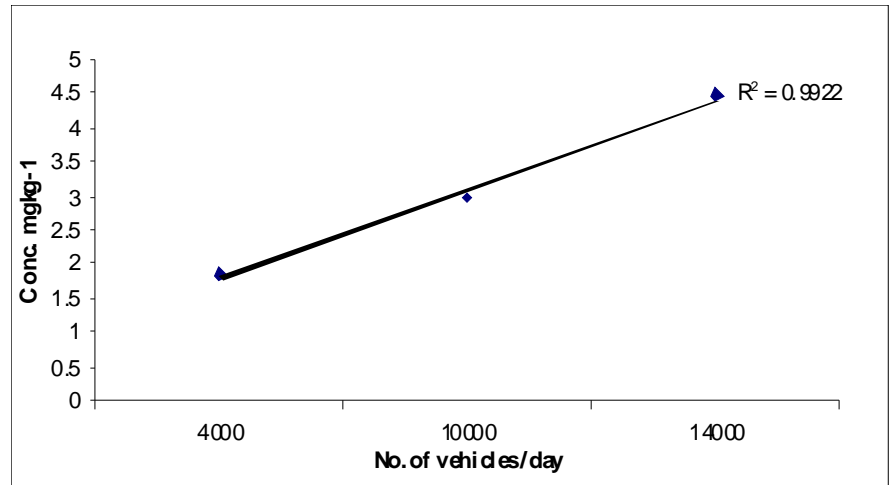

Fig. 21: Correlation of Cd levels in surface soils with traffic density

traffic density and Cd concentrations.

In all sections of the road, metal levels decreased with increasing distance from the road and at lower depths. There was also a reduction in all metals levels in moving from section A to C. It can be concluded then that vehicular traffic is the major contributing factor to the levels of heavy metals in roadside soils. The trend in the levels for all the heavy metals in these soils is section $\mathrm{A}>$ section $\mathrm{B}>$ section $\mathrm{C}$ whether at $5 \mathrm{~m}, 20 \mathrm{~m}$ or $50 \mathrm{~m}$ from the road. Comparison of total $\mathrm{Pb}$ and $\mathrm{Zn}$ levels with WHO threshold values of $500 \mathrm{mgkg}^{-1}$ and $300 \mathrm{mgkg}^{-1}$ respectively show that $\mathrm{Pb}$ and $\mathrm{Zn}$ contamination was evident only in section A of the road. In this section, soils up to $50 \mathrm{~m}$ distance from the road were contaminated with $\mathrm{Pb}$ and $\mathrm{Zn}$. There was no contamination by $\mathrm{Pb}$ or $\mathrm{Zn}$ at any point in sections $\mathrm{B}$ and $\mathrm{C}$. $\mathrm{Cu}$ contamination $\left(>50 \mathrm{mgkg}^{-}\right.$ ${ }^{1}$ ) up to $50 \mathrm{~m}$ from the road was evident in sections $\mathrm{A}$ and $\mathrm{B}$. There was however no $\mathrm{Cu}$ contamination at any point in section $\mathrm{C}$. In sections $\mathrm{A}$ and $\mathrm{B}$, soils up to $20 \mathrm{~m}$ from the road were contaminated with $\mathrm{Cd}\left(>2 \mathrm{mgkg}^{-1}\right)$. However, none of the soils at $50 \mathrm{~m}$ from the road were contaminated with $\mathrm{Cd}$. Similarly, none of the soils at any point in section $\mathrm{C}$ was contaminated by any of the metals.

\section{CONCLUSION}

The distribution of $\mathrm{Pb}, \mathrm{Cu}, \mathrm{Zn}$ and $\mathrm{Cd}$ in soils collected from different distances and depth along the Tafo-Aboaso road in Kumasi in the Ashanti region of Ghana were as a result of aerial deposition of metals in the soils. The correlation between total heavy metals and soil depth and distance from the road indicated a reduction in metals levels at lower depths. The socio-economic impacts caused by vehicular activities cannot be disassociated from the metal pollution environmental and health impacts in exposed areas themselves. This study therefore recommends that, require monitoring, and preventive measures like banning leaded gasoline use should always be systemically integrated into national policy.

\section{REFERENCES}

Abduljaleel, S. A., Shuhaimi-Othman, M. and Babji, A. (2012). Assessment of Trace Metal Contents in Chicken (Gallus gallus domesticus) and Quail (Coturnix coturnix japonica) Tissues from Selangor (Malaysia). Journal of Environmental Science Technology, 5(6):441 $-451$.

Abechi, E. S., Okunola, O. J., Zabairu, S. M. J., Usman, A. A. and Apene, E. (2010). Evalua- 
tion of heavy metal in roadside soils of major streets in Jos metropolis, Nigeria. Journal of Environmental Chemistry and Ecotoxicology, 2 (6): 98-102.

Adedeji, O. H., Olayinka, O. O. and Oyebanji, F. F. (2013). Assessment of Traffic Related Heavy Metals Pollution of Roadside Soils in Emerging Urban Centres in Ijebu-North Area of Ogun State, Nigeria. Journal of Applied Science Environment Management, 17 (4):509-514.

Bai, J., Cui, B., Wang, Q., Gao, H. and Ding, Q. (2008). Assessment of heavy metals contamination of roadside soils in West China. Stochastic Environmental Research and Risk Assessment, 23:341-347.

Bakirdere, S. and Yaman, M. (2008). Determination of lead, Cadmium and Copper in roadside soil and plants in Elazig, Turkey. Environmental Monitoring Assessment, 136:401410.

Chow, T. L. (1970). Lead accumulation in roadside soil and grass. Nature, Lond. 225: 295-296.

Hjortenkrans, D. Bergback, B. and Haggerud, A. (2006). New metal emission patterns in road traffic environments. Environmental Monitoring and Assessment, 117: 85-98.

Lagerweff, J. V. and Specht, A. W. (1970). Contamination of roadside soil and vegetation with $\mathrm{Cd}, \mathrm{Ni}, \mathrm{Pb}$ and $\mathrm{Zn}$. Environmental Science Technology, 4: 583-586.

Mahaffey, K. R. (1977). Relation between quantities of lead ingested and health effects of lead in humans. Pediatrics, 59: 448-456.

Motto, H. L., Daines, H. R.., Chilko, D. M. and Motto, K. C. (1970). Lead in soils and plants: its relation to traffic volume and proximity to highways. Environmental Science Technology, 4: 231-7.

Naser, H. M., Sultana, S., Gomes, R. and Noor, S. (2012). Heavy metal pollution of soil and vegetable grown near roadside at Gazipur. Bangladesh Journal Agricultural Research, 37(1): 9-17.

Page, A. L., Miller, R. H. and Keeney, D. R. (1971). Methods of soil analysis. Part 2. Chemical and Microbiological Properties, Agronomy Series No. 9 (Part 2). American Society of Agronomy, Inc. and Soil Science of America, Inc., Madison, WI., pp. 539-579.

Page, A. L. and Bingham, F. T. (1973). Cadmium residues in the environment. Residue Revision, 48: 1-43.

Rodrigues-Flores, M. (1982). Lead and cadmium levels in soil and plants near highways and their correlation with traffic density. Environmental Pollution Series B, 4: 281-281.

Swietlik, R, Strzelecka, M. and Trojanowska, M. (2013). Evaluation of Traffic-Related Heavy Metals Emissions Using Noise Barrier Road Dust Analysis. Polish Journal of Environmental Studies, 22: 561-567.

Voegborlo, R. B. and Chirgawi, M. B. (2007). Heavy metal accumulation in roadside soil and vegetation along major highways in Libiya. Journal of Science and Technology, 27 (3): 1-12. 